DOI: $10.31249 / \mathrm{rsm} / 2021.04 .04$

\title{
Б.А. Шмелев
}

\section{СОЦИААЬНО-ПОАИТИЧЕСКАЯ ТУРБУАЕНТНОСТЬ НА ПОСТСОВЕТСКОМ ПРОСТРАНСТВЕ: ПРИЧИНЫ И ПОСАЕАСТВИЯ}

Аннотация. В статье анализируются социально-политические процессы на постсоветском пространстве, приводящие к возникновению конфликтов как внутри собственно Новых Независимых Государств СУU, так и между ними. Сочиильнополитическая турбулентность в регионе является составной частью нестабильности, охвативщей огромный регион, простирающийся от Восточной Европы до Тихого океана. Здесь сосредоточена большая часть конфликтов, подрываюших не только региональную, но и глобальную стабильность.

В статье отмечается, что, хотя природа конфликтов и динамика эволючии в различных странах, расположенных на этой огромной территории, различаются, их объединяет поиск своей идентичности, приводящий к межгосударственным конфликтам или внутригосударственным кризисам. Социильно-экономические факторы, ранее доминировавшие при определении состояния политической действительности и разделявшие политические партии на правые и левые, постепенно уступают место политическим силам, борюшимся за утверждение своего понимания идентичности в обществе. Часто столкновение сторонников и противников разных концепций идентичности, означающих различные векторы сочиильного и геополитического развития страны, приводят к жесткому противостоянию политических партий и движений. Как отмечает автор, борьба за утверждение различных моделей идентичности в ННГ будет определять политический ландиафт в обозримом будущем.

Поиск идентичности сопровождается утверждением идеологии национализма как основы государственного строчтельства, что часто ведет к межгосударственным конфликтам, в том числе и в форме вооруженных столкновений. В статье рассматривается вопрос о соотношении идеологии нащионализма и исламизма в странах Центральной Азии и последствия усиления его влияния в центральноазиатских странах на характер их отношений с Россией.

Большое внимание автор уделяет исследованию роли циивлизационного и геополитического факторов в возникновении социально-политической турбулентности на постсоветском пространстве. Здесь происходит не только борьба между различнылм центрами силь за подчинение развития ННГ своим региональным и глобальным интересам, но речь также идет и о стремлении различных циивилизаций втянуть их в зону своего гравитационного притяжения, что в совокупности размывает геополитическое единство постсоветского пространства и превращает его из субъекта в объект современных международных отношений. 


\section{РОССИЯ И МИР В ХХІ ВЕКЕ}

По мнению автора, основные тенденции развития постсоветского пространства свидетельствуют о том, что оно остается и останется зоной растущей конфликтогенности, приводящей к усилению его дезинтеграции. ННГ не ориентируются в своей политике на усиление интеграчии во главе с $Р \Phi$, а в рамках проводимого ими многовекторного внешнеполитического курса стараются балансировать в первую очередь между Россией и Западом, а в последнее время и между РФ и Китаем.

Статья написана на основе материалов международной научной конференции «Причины роста сочиально-политической турбулентности на постсоветском пространстве. Последствия для России», состоявшейся 24 марта 2021 г. в Институте эконолики РАН. В ней приняли участие сотрудники научно-исследовательских институтов Москвы, политологи и эксперты из Украины, Белоруссии, Армении, Грузии и Казахстана.

Ключевые слова: идентичность; многовекторность; национализм; интеграция; конфронтация; турбулентность; кризис; постсоветское пространство.

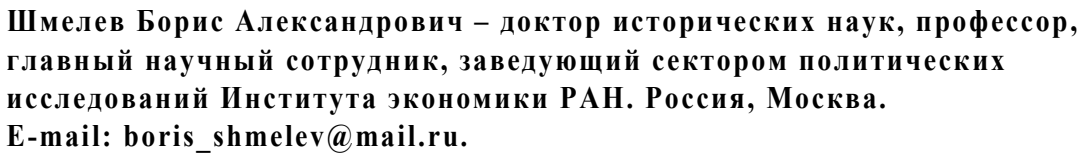

\section{Shmelev B.A. Social and political turbulence in the post-Soviet space: causes and consequences}

Abstract. The article analyses the socio-political processes in the post-Soviet space, leading to the emergence of conflicts both within and between the Newly Independent States of CYU. The socio-political turbulence in the region is an integral part of the instability that has engulfed a vast region, stretching from Eastern Europe to the Pacific Ocean. Most of the conflicts that undermine not only regional but also global stability are concentrated here.

The article notes that although the nature of conflicts and the dynamics of their evolution in different countries located in this vast territory are different, they are united by searching for their identity, leading to interstate conflicts or internal crises. The socioeconomic factors that dominated the state's development and divided the political parties on the right and the left gradually gave way to political forces struggling to assert their understanding of identity in society. Often, the clash of supporters and opponents of different concepts of identity, meaning different vectors of the country's social and geopolitical development, leads to a tough confrontation of various political parties and movements, in their intensity not inferior to the outgoing class struggle.

As the author notes, the struggle to establish different models of identity in the NIS will determine the political landscape in the foreseeable future. The search for identity is accompanied by the assertion of the ideology of nationalism as the basis of state-building, which often leads to interstate conflicts, including armed clashes. The article deals with the correlation between nationalism and Islamism in Central Asian countries and the consequences of its increasing influence in Central Asian countries on the nature of its relations with Russia. 
The author pays great attention to studying the role of civilizational and geopolitical factors in the emergence of socio-political turbulence in the post-Soviet space. Not only is there a struggle between the various Centers of Power to subordinate the development of the NIS to its regional and global interests, but it is also about the desire of various civilizations to draw them into the zone of their gravitational pull. These cases together erode the geopolitical unity of the post-Soviet space and transform it from a subject into an object of modern international relations.

According to the author, the main trends in the development of the post-Soviet space show that it remains and will remain a zone of growing conflicts, leading to the strengthening of its disintegration. The NIS is not oriented in its policy to strengthen integration, led by the Russian Federation, but within the framework of their multi-vector foreign policy are trying to balance primarily between Russia and the West, and more recently between Russia and China.

The article is written based on the materials of the international scientific conference "The reasons for the growth of socio-political turbulence in the post-Soviet space. Consequences for Russia», held on March 24, 2021, at the Institute of Economics of the Russian Academy of Sciences.

Keywords: identity; multi-vectors; nationalism; integration; confrontation; turbulence; crisis; post-Soviet space.

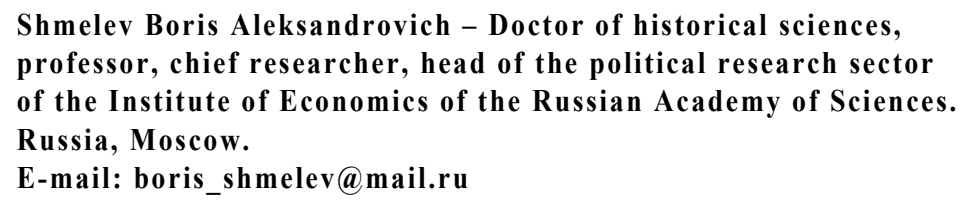

Shmelev Boris Aleksandrovich - Doctor of historical sciences, professor, chief researcher, head of the political research sector of the Institute of Economics of the Russian Academy of Sciences. Russia, Moscow.

E-mail: boris_shmelev@mail.ru

Политические кризисы в Республике Беларусь, Молдове, Грузии, Украине, Армении, а также российско-украинский, армяно-азербайджанский, киргизотаджикский конфликты свидетельствуют о высокой степени социальнополитической турбулентности на постсоветском пространстве, подрывающей стабильность в регионе и несущей угрозу безопасности не только на региональном, но и на глобальном уровнях. Как отмечал еще в начале XXI в. Збигнев Бжезинский, «в течение следующих нескольких десятилетий самым нестабильным и опасным регионом планеты, готовым в любой момент взорваться и ввергнуть мир в пучину хаоса, будет часть Евразии между Европой и Дальним Востоком» [Бжезинский 2004, с. 187]. Он называл эту территорию «новыми глобальными Балканами», с тем, чтобы «привлечь внимание к геополитическому сходству... между регионом и европейскими Балканами XIX и XX веков», так как внутренняя нестабильность послужила поводом для внешней интервенции со стороны основных держав мира и соперничества между ними» [Бжезинский 2004, с. 187].

Прогноз Бжезинского оказался верным. За последние 20 лет нового столетия социально-политическая турбулентность в регионе нарастала в том 
числе и за счет ее усиления на постсоветском пространстве, которое можно рассматривать как своеобразный субрегион Большой Евразии. Как отмечал известный российский политолог Александр Панарин, «стратегическая нестабильность, по всей видимости, уже стала судьбой XXI века - вопреки всем ожиданиям “стабильного развития”» [Панарин 2003, с. 9].

Новые независимые государства вносят в формирование «стратегической нестабильности» в современном мире весьма существенный вклад и можно предполагать, что в перспективе он будет только возрастать.

При всем разнообразии причин социально-политических кризисов на постсоветском пространстве, их объединяет одно качество, им всем присущее все они возникли в результате поиска новыми независимыми государствами своей новой идентичности и нежеланием мириться с установившимся статускво. Как отмечает Френсис Фукуяма, на смену противостоянию по экономическим вопросам «выходит конфликт, связанный с определением идентичности» [Фукуяма 2019, с. 43]. По словам венгерского премьер-министра Виктора Орбана, «... группа - будь то великая держава, такая как Россия или Китай, или избиратели в США или Великобритании - считает, что обладает идентичностью, которая не получает адекватного признания со стороны внешнего мира, когда речь идет о нации, или со стороны других членов своего общества. Такие идентичности могут быть - и остаются - невероятно разнообразными в зависимости от принадлежности к той или иной нации или государству, тем или иным религиозным убеждениям, в зависимости от этнической принадлежности, сексуальной ориентации или пола. Все они являются проявлениями общего феномена - политики идентичности» [Фукуяма 2019, c. 45].

Анализируя современные политические процессы в мире, он приходит к выводу, что «существенная часть политических конфликтов современного мира - от демократических революций до новых социальных движений, от национализма и исламизма до политических столкновений в университетских кампусах современной Америки - можно свести к проявлениям политики идентичности» [Фукуяма 2019, с. 47].

Конечно, только с помощью политики идентичности невозможно объяснить причины возникновения всех кризисов на постсоветском пространстве. Экономические факторы по-прежнему выступают здесь в качестве важнейшей детерминанты возникновения кризисов, но и они не все определяют в логике их появления и эволюции.

Оборотной стороной политики идентичности является национализм, который ориентирует общество на концентрацию всех его духовных и материальных сил на построение сильного национального государства, способного занять достойное место в окружающем мире [Ioffe 2021, с. 157-159]. 
Национализм в ННГ представляет собой действенное средство канализации социальной энергии населения в интересах правящей элиты, которая с его помощью стремится упрочить свои политические позиции в обществе. Такая политика не является ее изобретением, она применялась в европейских государствах в течении XIX-XX вв., но в конечном итоге принесла ее создателям горькие плоды в виде либо краха, либо глубокого кризиса государственности. Достаточно посмотреть на историю балканских государств. То же самое ожидает и постсоветские государства, которые взяли на вооружение в процессе государственного строительства идеологию национализма.

После распада Советского Союза и краха коммунистической идеологии правящая элита за неимением ничего лучшего взяла на вооружение идеологию национализма. Попытки в странах Центральной Азии и Азербайджане насадить идеологию исламизма были встречены в штыки и потерпели поражение как на поле боя, как это произошло в Таджикистане, так и в политической борьбе, как в Азербайджане и Узбекистане [Уяма 2021, с. 56-70]. Светский характер государства на основе светской идеологии национализма удалось сохранить, что можно расценивать как несомненно позитивный фактор развития всего постсоветского пространства. Но одновременно национализм стал проявлять свои присущие ему агрессивные черты: нетерпимое отношение к другим народам, проживающим на территории данного государства, проведение политики ассимиляции с помощью ограничения использования своего родного языка или его выдавливание за пределы страны, агрессивное отношение к соседним государствам. Наиболее отчетливо эти тенденции проявляются в политике Киева, Баку и Еревана. Конечно, как показывает исторический опыт, национализм представляется неизбежным политическим феноменом на этапе строительства нации и государственности. Многие народы, получив после распада СССР независимость, не имели до этого своей государственности и исторического опыта строительства независимого государства, в них не была сформирована своя государствообразующая нация. И в этих условиях национализм представляет собой самый эффективный механизм формирования национального самосознания и строительства национального государства. Демократия в западном варианте не прижилась в силу неразвитости общественного сознания, клановой структуры общества, отсутствия исторических традиций жизнедеятельности в условиях демократии. В большинстве из них установился режим автократии, опирающийся на идеологию национализма, как наиболее удобную для управления обществом и понятную населению. В Украине, Молдове, Грузии сформировался режим псевдодемократии, который также опирается на идеологию национализма.

Наиболее одиозной является идеология украинского национализма. В начале XX в. творцы украинской национальной идеи исходили из представления о необходимости создания независимого украинского национального 
государства, разрыва с русской культурной традицией. Они видели в российском государстве главного врага украинской государственности. Поэтому, чтобы выстоять в противостоянии с Россией, украинское независимое государство должно опираться на помощь и поддержку европейских государств, в первую очередь Германии. Будущее украинское государство с геополитической точки зрения определялось ими в качестве своеобразного буфера между Европой и Россией, которая, по мнению украинских националистов, являлась азиатской страной.

Историческая миссия независимого украинского государства виделась ими в сдерживании России от проникновения в Европу и распространения на нее российского влияния [Донцов 2017, с. 15]. Поскольку украинская нация в тот период еще не сформировалась, то большое значение придавалось конструированию и распространению украинского языка, созданию мифологизированной украинской истории и ее героев, стремлению оторвать Украину от истории русского народа, российского государства как основы ее становления.

Будущее украинское национальное государство большинству тогдашних идеологов украинской национальной идеи не представлялось как этнократическое, но становление украинской нации подразумевало ассимиляцию русского населения, проживающего на его территории, с помощью в первую очередь вытеснения русского языка из образования, культуры, средств массовой информации, превращения украинского языка в единственный государственный. Для некоторых из них характерной была антирусскость, стремление видеть в русских врагов украинского независимого государства.

Таким образом, в основе украинской национальной идеи с самого начала лежали три основополагающих положения. Российское государство представлялось врагом украинской независимости и поэтому в интересах Украины - его ослабление, а еще лучше распад. Русское население представляет собой серьезное препятствие на пути становления независимого украинского государства, и поэтому оно должно быть ассимилировано. Независимость же Украины может быть обеспечена только благодаря тесному сотрудничеству с европейскими странами, которые помогут ей в отстаивании этой независимости, так как Украина является частью Европы в отличие от азиатской России. На основе этих идейных положений предполагалось сформировать украинскую идентичность [Украинский вопрос 2016, с. 265, 293, 302].

В таком виде национальная украинская идея содержала в себе очень большой заряд конфликтности с Россией, неизбежно вела к столкновению их геополитических интересов [Толочко 2018, с. 137-144].

Провозглашение в 1991 г. независимости Украины означало возникновение второго русского государства, население которого нужно было преобразовать в украинскую нацию. Правящая политическая элита страны при поддержке украинской интеллигенции в качестве идейной основы строительства 
украинского национального государства взяла на вооружение основные постулаты украинской национальной идеи, которые оформились еще в первой половине XX в. и положила их в основу своей внешней и внутренней политики. Все украинские президенты, хотя и с разной степенью решительности и последовательности, реализовывали эти идеи. В наибольшей мере им были привержены В. Ющенко, П. Порошенко, а также и нынешний украинский президент В. Зеленский. Все украинские президенты ориентировались на вхождение страны в ЕС, т.е. в систему европейской экономической интеграции, и в НАТО, т.е. в систему евроатлантической безопасности. При них были предприняты меры по вытеснению русского языка из сферы образования, культуры, из информационного пространства, что вело к ассимиляции русского населения в стране. Вся политика, проводимая по укреплению независимости страны, подразумевала и подразумевает независимость от России, которая рассматривается как главная угроза национальной безопасности молодого украинского государства. На этой основе украинская политическая, интеллектуальная и бизнес-элита строят украинскую идентичность.

Присоединение Россией Крыма и поддержка борьбы самопровозглашенных ДНР и ЛНР против киевской власти в качестве ответа на государственный переворот, осуществленный националистическими силами в Киеве в феврале 2014 г. были расценены на Украине как акт агрессии. В результате украинское государство встало на путь жесткой конфронтации с РФ. Для ее преодоления потребуется немало времени и сил и на обозримую историческую перспективу отношения между двумя странами будут строиться на принципах игры «с нулевой суммой». В этих условиях говорить о партнерстве и сотрудничестве не приходится, так как речь идет о взаимоотношениях двух враждебных государств. Максимум, на что можно рассчитывать - это на поддержание «холодного мира» между ними, но и то при условии нормализации отношений между Россией и Западом, устранения новой «холодной войны».

Наряду со столкновением российской и украинской идентичностей, что породило кризис российско-украинских отношений и отношений между Россией и Западом, существенным фактором социально-политической турбулентности является и конфликт идентичностей в самой Украине в лице Киева, с одной стороны, и самопровозглашенных ДНР и ЛНР - с другой. Эти две республики совершенно иначе представляют свое будущее, не связывая его с нынешним украинским государством. Они бы предпочли либо войти в состав России, либо развиваться как независимые государства в союзе с Россией. Минские договоренности удерживают ДНР и ЛНР от принятия радикальных шагов по провозглашению своей независимости. Поэтому они вынуждены добиваться поддержания сложившегося статус-кво, что не отвечает интересам Киева, который хочет вернуть эти территории под свой суверенитет. Возможности урегулирования этого конфликта в настоящее время не просматриваются 
и, судя по всему, еще долго он будет играть роль дестабилизирующего фактора не только в регионе, но и на всем европейском континенте [Украинский кризис 2020, c. 9].

Кризисы на постсоветском пространстве, ведущие к нарастанию социально-политической турбулентности, возникли также в результате исторической нелегитимности границ бывших советских республик. В момент распада СССР лидерами новых независимых государств межреспубликанские административные границы единогласно были признаны в качестве межгосударственных. Но в Советском Союзе эти границы были произвольно определены руководством, исходя из потребностей строительства социалистического государства.

Однако после распада СССР государственные границы ННГ часто не соответствовали требованиям этнокультурного, исторического, геополитического развития как самих государств, так и проживающих на их территориях народов. Вследствие этого подрывалась стабильность не только внутри государств, но и провоцировалась напряженность в соседних странах, затрагивались интересы обеспечения их национальной безопасности, что ведет к возникновению как внутригосударственных, так и межгосударственных конфликтов.

В статье «Об историческом единстве русских и украинцев» Президент РФ В.В. Путин отмечает, что «в СССР границы между республиками, конечно же, не воспринимались как государственные, носили условный характер в рамках единой страны». По его мнению, если «часть одного народа в ходе своего развития может осознать себя отдельной нацией и захочет создать свое собственное государство, то республики, учредители Союза, после того как они сами же аннулировали Договор 1922 года, “должны вернуться в те границы, в которых они вступили в состав Союза. Все же остальные территориальные приобретения - это предмет для обсуждения, переговоров...”. Иными словами, как отмечает президент в своей статье, уходить нужно с тем, “с чем пришли”» [Путин 2021]. Это заявление российского президента перечеркивает решения АлмаАтинского саммита декабря 1991 г., на котором была достигнута договоренность между руководителями бывших советских республик о признании межреспубликанских административных границ в качестве межгосударственных, а также ставит под вопрос легитимность существующих на постсоветском пространстве границ, что существенно увеличивает неопределенность его развития. В Декларации говорилось о признании и уважении территориальной целостности друг друга и нерушимости существующих границ [Алма-Атинская Декларация].

Социально-политическая турбулентность на постсоветском пространстве обусловливается также и возникающими здесь «цветными революциями». У этого термина не имеется точного определения, но в основном под ним 92 
понимается смена правящего режима, осуществляемая преимущественно с использованием ненасильственных методов борьбы в виде массовых уличных акций протеста.

Причины, по которым в ННГ возникают «цветные революции», различны, но их объединяет желание различных социальных слоев в этих государствах добиться смены правящих режимов. Эти революции являются спонтанной реакцией общества на существующие противоречия общественной жизни, которые заводят в тупик социально-экономическое развитие страны. Внутриполитические кризисы в виде «цветных революций» имеют свое международное измерение, так как в той или иной степени затрагивают геополитические интересы либо соседних государств, либо великих государств. Зачастую происходит активное вмешательство во внутренние конфликты с тем, чтобы добиться их урегулирования в нужном направлении. И ННГ становятся полем столкновения геополитических устремлений различных государств, в первую очередь великих держав, что ведет к дальнейшему обострению внутриполитического противостояния, к росту напряженности в регионе.

Россия в этих условиях оказывается перед сложным выбором. Как говорится во Всеобщей Декларации прав человека, «необходимо, чтобы права человека охранялись властью закона в целях обеспечения того, чтобы человек не был вынужден прибегать в качестве последнего средства к восстанию против тирании и угнетения», т.е. право на восстание рассматривается как естественное право граждан на сопротивление против узурпации власти тогда, когда мирные политические средства борьбы исчерпали себя. И с этим принципом РФ не может не считаться [Всеобщая Декларация прав человека]. В то же время все «цветные революции» имеют весьма существенный геополитический подтекст, так как их лидеры в той или иной форме заявляют о своей геополитической и геоэкономической переориентации сотрудничества с Россией на углубление взаимодействия с НАТО, ЕС, США, т.е. речь идет об утверждении новой внешнеполитической идентичности. Вопросы взаимоотношений с Москвой становятся, таким образом, важнейшим элементом внутриполитической борьбы.

РФ расценивает такую смену геополитических и геоэкономических вех, как угрозу своей национальной безопасности, что в условиях «холодной войны» с коллективным Западом является реальностью. Поэтому в принципиальном плане РФ видит в «цветных революциях» дестабилизирующее явление на постсоветском пространстве, один из существенных факторов в геополитическом противостоянии в первую очередь с США. В своем выступлении на заседании Совета Безопасности В.В. Путин приравнял «цветные революции» к экстремизму, который, по его словам, используется в современном мире как инструмент геополитики и передела сфер влияния [Путин 2014]. 


\section{РОССИЯ И МИР В ХХІ ВЕКЕ}

С российской точки зрения под предлогом демократизации внутренние социально-экономические и политические проблемы используются для того, чтобы сменить неугодные правительства на контролируемые извне режимы, что представляет собой «новую форму войны» [Countering 2014].

Оценивая таким образом «цветные революции» на постсоветском пространстве, Россия достаточно сдержанно относится к ним до тех пор, пока напрямую не задеваются ее геополитические интересы или интересы национальной безопасности. Тогда следует жесткая реакция, не исключающая зачастую применения вооруженной силы. Так, были предприняты решительные действия в отношении Украины после прихода к власти в результате государственного переворота в Киеве украинских националистов в феврале 2014 г., что вынудило российское руководство принять срочные меры по воссоединению Крыма с Россией.

Россия готова всеми возможными способами поддержать режим Лукашенко в его противостоянии с белорусским оппозиционным движением, опасаясь, что если к власти придут оппозиционеры, вектор геополитической ориентации Минска может измениться с пророссийского на прозападный, что является неприемлемым для Москвы.

Политический кризис в Беларуси представляет собой весьма серьезный вызов интересам безопасности России. Как отмечают белорусские политологи, в Беларуси установился «жесткий авторитарный режим. Беларусь из острова стабильности в обозримом будущем становится "больным человеком Европы” и постсоветского пространства» [Карбалевич 2021, с. 27].

Москвой была определена своеобразная красная линия, которую ННГ не должны ни в коем случае пересекать. Это - вступление в НАТО, смена вектора геополитической ориентации с пророссийского на прозападный и притеснение русскоязычных граждан. С другими переменами во внешней и внутренней политике ННГ под влиянием «цветных революций» Россия готова мириться, считая их внутренним делом отдельного государства. Но дело в том, что в новых независимых государствах выросло новое поколение постсоветских людей, у которых сформировался ярко выраженный запрос на справедливость, честное правосудие, достойную жизнь, на борьбу с коррупцией, клановостью, непотизмом. Реализовать эти устремления они рассчитывают в том числе и с помощью Запада, что создает предпосылки для укрепления западного влияния на постсоветском пространстве. И Россия противопоставить этому тренду свою концепцию развития не в состоянии. По существу, она проводит в регионе охранительную политику, стремясь законсервировать сложившийся статус-кво. Когда же стабильность нарушается в силу естественной эволюции общества, России приходится вмешиваться, чтобы не допустить ослабления своих позиций в регионе. Россия в настоящее время не в состоянии удовлетворить ценностные запросы развивающихся обществ ННГ, 
так как не может ответить на них в своем собственном развитии, что во многом определяет и будет определять характер взаимоотношений между ними и РФ.

Наряду с противоречивым процессом поиска своей идентичности на уровень социально-политической стабильности на постсоветском пространстве влияют достижения в социально-экономическом развитии ННГ. Достигнутые результаты в этой области существенно различаются. Наибольших успехов достигли страны, обладающие значительными запасами углеводородного сырья. Им удалось с большой выгодой для себя использовать сложившуюся конъюнктуру на мировых рынках углеводородного сырья и направить полученные немалые средства на модернизацию своей экономики.

Однако большая часть ННГ добилась весьма скромных результатов в своем экономическом развитии, а Украина, Таджикистан и Молдова даже не достигли уровня 1990 г. За истекшие 30 лет после распада СССР европейские страны, не говоря уж о Китае, сделали большой рывок в своем социальноэкономическом развитии, и на их фоне показатели состояния экономики ННГ не производят сильного впечатления [Вардомский 2017]. Очевидно, что они отстали от развитых европейских стран навсегда и догнать их не смогут, если в них не наступит всеохватывающий социально-политический и экономический кризис. Как следствие, низкий уровень жизни населения, растущее социальное расслоение, усиливающиеся под воздействием пандемии, создает предпосылки для возникновения глубокого политического кризиса с непредсказуемыми последствиями для безопасности во всем регионе.

ННГ являясь по объему ВВП и численности проживающего в них населения малыми и средними странами, не в состоянии успешно развиваться, опираясь лишь на свои собственные ресурсы. Они нуждаются во внешнем драйвере для проведения политики модернизации своей экономики как важнейшего условия обеспечения социально-политической стабильности. Украина, Грузия, Молдова взяли курс на интеграцию в ЕС. Таджикистан и Туркменистан видят в Китае и предложенном им интеграционном проекте «Один пояс - один путь» реальную возможность вывести свою экономику на новый уровень развития. Однако большинство ННГ хотело бы, чтобы роль драйвера для них играла Россия [Россия и постсоветские страны 2021]. В России проживают влиятельные диаспоры, которые играют роль связующего звена, российские рынки расположены рядом с этими странами, Москва обладает значительным инвестиционным потенциалом, в привлечении которого ННГ весьма заинтересованы.

Однако выступать в таком качестве Москве крайне сложно, так как страна уже восемь лет переживает экономический кризис, который еще более усугубился пандемией. В этих условиях ННГ рассчитывают с помощью ЕС, КНР, США и Турции решить те многочисленные социально-политические проблемы, с которыми они сталкиваются. Следствием такой политики является ослабление влияния РФ в регионе, размывание ее геополитических 
позиций. И эта тенденция стала устойчивой. Украина, Грузия, а также судя по всему, Туркменистан и Молдова, с геополитической точки зрения для России потеряны. Маловероятно, чтобы их внешняя политика развернулась в сторону военно-политического сотрудничества с Москвой [Кунце, Фогель 2020].

С учетом наметившихся политических процессов на постсоветском пространстве не приходится говорить о строительстве «русского мира», собирании земель вокруг России, превращении постсоветского пространства в зону преимущественных интересов России. Для этого у нее не имеется достаточного политического и экономического потенциала. Значит ли это, что Москве следует сосредоточить имеющиеся у нее ресурсы в первую очередь только на углублении сотрудничества с Беларусью и Казахстаном, которое имеет для нее жизненно важное значение, предоставив развитие отношений с другими ННГ естественному ходу событий, т.е. снять с себя политическую ответственность за обеспечение безопасности в регионе. Это означало бы переход к проведению пассивной политики, что будет иметь далеко идущие геополитические последствия для РФ. Количество враждебных ей государств в регионе увеличилось бы, пришлось бы забыть о создании пояса добрососедства. Вполне возможно создание санитарного кордона вокруг РФ. Поэтому, используя «мягкую силу», Россия должна бороться за сохранение своего влияния на ННГ, для чего необходимо форсировать экономическое развитие с тем, чтобы существенно увеличить имеющийся потенциал.

Социально-политическая турбулентность на постсоветском пространстве вызвана и столкновением двух цивилизаций - западнохристианской и православнохристианской в лице русской субцивилизации. Наиболее остро этот процесс проявляется в Украине. Поэтому от исхода украинского кризиса будет зависеть не только будущее украинского и российского государств, но и православной и самой русской субцивилизации. Как показывает исторический опыт, каждая цивилизация стремится, с одной стороны, «к сохранению и приумножению своих материальных и культурных ценностей, к самосохранению общности как единого целого», а с другой - «к максимально возможному расширению», которое «осуществляется посредством экспансии, направленной на захват территории ...контроля и влияния над материальными и людскими ресурсами соседей... на распространение во вне своих культурных ценностей» [Киселев 2002, с. 5]. Жизнеспособность цивилизации определяется ее способностью к экспансии - экономической, культурной, геополитической. Потеря этой способности означает начало ее угасания. С этой точки зрения вступление Украины, Грузии, Молдовы в ЕС и НАТО, принятие их политических, военных, социальных и хозяйственных стандартов означает переход в другой цивилизационный ареал, что ослабляет позиции России как стержневого государства православнохристианской цивилизации. По определению С. Хантингтона, в настоящее время 96 
«глобальная политика - это политика цивилизаций. Соперничество сверхдержав сменилось столкновением цивилизаций» [Хантингтон 2006, с. 22].

Поэтому столкновение России и Запада на постсоветском пространстве было объективно неизбежно. Это не исключает возможности сотрудничества между ними в решении конкретных вопросов региональной безопасности. Но Россия и Запад будут оставаться соперниками, пристально следящими за действиями противной стороны и готовыми дать отпор, если ущемляются их цивилизационные и геополитические интересы. Исходя из этого постулата, американский политолог Дж. Миршеймер еще в начале 1990-х годов отмечал, что переход Украины в другой цивилизационный ареал «может развязать (между Россией и Украиной. - Б. Ш.) соперничество по вопросам безопасности. Россия и Украина могут преодолеть эту динамику и сосуществовать в гармонии, но это будет весьма необычное развитие ситуации» [Хантингтон 2006, c. 39].

Последующее развитие российско-украинских отношений подтвердило правоту его вывода. Украина, чтобы стать Европой, по существу, должна пересмотреть свою цивилизационную идентичность. Необходимые предпосылки в стране для этого имеются. Украинская политическая и экономическая элиты, а также значительная часть населения активно поддерживают курс на вхождение в Европу. Проведенные в 2020 г. Киевским международным институтом социологии опросы показали, что $41 \%$ украинцев высказались «за» вступление в НАТО, $35 \%$ - за нейтралитет страны, $12 \%$ - за присоединение к ОДКБ, и 11\% затруднились ответить [Суспільно-політичні 2020].

Процесс цивилизационной переориентации занимает немало времени и является крайне болезненным по своим политическим, социальным и культурным последствиям. По словам С. Хантингтона, «на данный момент этот процесс нигде не увенчался успехом» [Хантингтон 2006, с. 210]. Поэтому Украине предстоит пережить немалые испытания и столкнуться с серьезными социально-политическими катаклизмами.

Там, где соприкасаются разные цивилизации, образуется «линия разлома», вдоль которой возникают внутригосударственные и межгосударственные кризисы и конфликты. В условиях противостояния России и Запада Москва стремится не допустить перехода православных Украины, Белоруссии, Молдовы, Грузии, Армении в западную зону геополитического влияния.

Значительная часть населения в них ориентируется на сотрудничество с Россией, как со стержневым государством православной цивилизации. Борьба за утверждение своей цивилизационной идентичности может принимать форму вооруженной борьбы, т.е. трансформироваться в гражданскую войну, в которую в той или иной форме вмешиваются другие государства. Именно это и происходит на Украине, через которую проходит линия межцивилизационного разлома, так как население Западной Украины привержено униатской 
церкви и в течении многих столетий входит в ареал западнохристианской цивилизации, в то время как остальная Украина исповедует православие. Линия разлома между ними сейчас проходит через Донбасс. Поэтому гражданская война в Донбассе, если ее рассматривать через призму отношений цивилизаций, представляет собой межцивилизационное столкновение как следствие отказа жить по лекалам другой цивилизации, принять чуждый цивилизационный код.

Рассматривая конфликт в Донбассе с этих позиций, политику России по поддержке самопровозглашенных ДНР и ЛНР следует расценивать не как вмешательство во внутренние дела другого государства, в чем ее обвиняет Запад, а как защиту своего цивилизационного ареала. Православная цивилизация и ее русская субцивилизация переживают спад, и поэтому РФ необходимо обеспечить условия для ее существования, в том числе и через поддержку жителей Донбасса. В соответствии с правилами развития цивилизаций, «если ты ослабляешь свое цивилизационное воздействие на других - усиливается давление соседних цивилизаций на тебя...» [Киселев 2002, с. 33].

\section{Библиография}

Алма-Атинская Декларация от 21 декабря 1991 года. https://docs.cntd.ru/document/190001 (дата обращения: 8.09.2021).

Бжезинский Зб. Зыбучие пески гегемонии // Россия в глобальной политике. 2004. Т. 2. № 2. С. 187-202.

Всеобщая Декларация прав человека (полный текст) https:/www.coe.int/ru/web/compass/ the-universal-deklaration-of-human-rights-full-version- (дата обращения: 8.09.2021).

Донцов Д. Ідеологія:Націоналізм. Незримі скрижалі Кобзаря. Маса и провід. Дух отари і дух провідництва. Харків: Фоліо, 2017. 571 с.

Карбалевич В. Беларусь. Пассионарный взрыв 2020 // Мир перемен. 2021. № 2. С. 19-27.

Киселев С. Основной инстинкт цивилизаций и геополитические вызовы России. М.: Известия, 2002. $368 \mathrm{c.}$

Кунце Т., Фогель Т. Падение СССР: Что стало с бывшими союзными республиками / пер. с нем. М.А. Перегудова, К.М. Арыкбаевой. М.: Кучково поле, 2020. 288 с.

Панарин А. Стратегическая нестабильность в XXI веке. М.: Алгоритм, 2003. 560 с.

Постсоциалистический мир: итоги трансформации: В 3 т. СПб.: Алетейя, 2017. Т. 2: Постсоветские государства. 454 с.

Путин В.В. Об историческом единстве русских и украинцев. URL: https://russian.rt. com/world/article/88468-putin-statya-rossiya-urraina (дата обращения: 7.09.2021).

Путин пообещал не допустить «цветной революции» в России. https:/www.bbc.com/ Russian/Russia/2014/11/141120_russia_putin_extremism (дата обращения: 25.02.2021).

Россия и постсоветские страны: вопросы экономических отношений / Отв. ред. А.Г. Пылин. М.: ИЭ РАН, 2021. 232 с.

Суспільно-політичні орієнтації населення України: квітень 2020. URL: https://www. kiis.com.ua/materials/pr/20200406_pressconf/Tables.pdf (дата обращения: 05.09. 2021).

Толочко П. Украина между Россией и Западом: историко-публицистические очерки. СПб.: Изд-во Санкт-Петербургск. гуманит. ун-та профсоюзов, 2018. 592 с. 
Украинский вопрос в русской патриотической мысли: сб. док. / Сост. А.Ю. Минаков. М.: Книжный мир, 2016. 800 с.

Украинский кризис: международное соперничество и пределы прочности государства / Под ред. Н.Ю. Силаева, А.А. Сушенцова. М.: Весь мир, 2020. 280 с.

Уяма Т. Влияние перемен периода перестройки на становление политических систем стран Центральной Азии: чувство угрозы и авторитаризм // Международная аналитика. 2021. T. 12. № 1. С. 55-70.

Фукуяма Ф. Политика достоинства и судьба либерального порядка. Феномен ресентимента после «конца истории» // Россия в глобальной политике. 2019. Т. 17. № 4. С. 40-51.

Хантингтон С. Столкновение цивилизаций / Пер. с англ. Т. Велимеева. М.: АСТ, 2006. 571 с.

Countering Color Revolutions: Russians New Security and its implications for U.S. Policy. URL: https://russiamil.wordpress.com/2014/09/15/countering-color-revolutions-russias-new-securitystrategy-and-its-implications-for-u-s-policy/ (дата обращения: 25.02.2021).

Ioffe G. Belarussian Nationalism: Taking Stock of Its Accomplishments // Международная Аналитика. 2021. T. 12. N 1. С. 146-161.

\section{References}

Alma-Atinskaia Deklaratsiia ot 21 dekabria 1991 goda [Alma-Ata Declaration from 21 December 1991]. URL: https://docs.cntd.ru/document/1900101 (date of access: 8.09.2021). (In Russ.)

Brzezinski Zb. Zybuchie peski gegemonii [The blue sands of hegemony]. Rossiia v global'noi politike [Russia in global politics]. 2004. Vol. 2. N 2. P. 187-202. (In Russ.)

Countering Color Revolutions: Russians New Security and its implications for U.S. Policy. URL: https://russiamil.wordpress.com/2014/09/15/countering-color-revolutions-russias-new-securitystrategy-and-its-implications-for-u-s-policy (date of access: 25.02.2021).

Donsov D. Ideologiia: Natsionalizm. Nezrimi skrizhali Kobzaria. Masa i provid. Dukh otari i dukh providnitstva [Ideology: Nationalism. The invisible Kobzar. The mass and seer. The spirit of Otari]. Harkiv: Follio, 2017. 571p. (In Ukr.)

Fukuyama F. Politika dostoinstva i sud'ba liberal'nogo poriadka. Fenomen resentimenta posle «kontsa istorii» [Politics of dignity and the fate of the liberal order. The phenomenon of resentiment after the «end of history»]. Rossiia v global'noi politike [Russia in global politics]. 2019. Vol.17. N 4. P. 40-51. (In Russ.)

Huntington S. Stolknovenie tsivilizatsii [Clash of Civilizations]. Trans. from eng. T. Velimeeva. Moscow: ACT, 2006. 571 p. (In Russ.)

Ioffe G. Belarussian Nationalism: Taking Stock of Its Accomplishments. Mezhdunarodnaia analitika [International analytics]. 2021. Vol. 12. N 1. P. 146-161.

Karbalevich V. Belarus'. Passionarnyj vzryv 2020. Mir peremen [Belarus. Passionate Explosion 2020. A world of change]. 2021. N 2. P. 19-27.

Kiselyov S. Osnovnoi instinkt tsivilizatsii i geopoliticheskie vyzovy Rossii [Basic instinct of civilizations and geopolitical challenges of Russia]: Moscow: Izvestia, 2002. 368 p. (In Russ.)

Kunze T., Vogel T. Padenie SSSR: Chto stalo s byvshimi soiuznymi respublikami [The Fall of the USSR: What Happened to the Former Soviet Republics] Trans. from germ. M.A. Peregudova, K.M. Arykbaeva. Moscow: Kuchkovo pole, 2020. 288 p. (In Russ.)

Panarin A. Strategicheskaia nestabil'nost' v XXI veke [Strategic instability in the 21 st century]. Moscow: Algorithm, 2003. 560 p. (In Russ.)

Postsotsialisticheskii mir: itogi transformatsii [Post-socialist world: the results of transformation]: 3 vol. St. Petersburg: Aleteia, 2017. Vol. 2: Postsovetskie gosudarstva [Post-Soviet States]. 454 p. (In Russ.) 


\section{РОССИЯ И МИР В ХХІ ВЕКЕ}

Putin poobeshchal ne dopustit' «tsvetnoi revoliutsii» v Rossii [Putin promised to prevent the «color revolution» in Russia. URL: https:/www.bbc.com/Russian/Russia/2014/11/141120_russia_ putin_extremism (date of access: 25.02.2021). (In Russ.)

Putin V.V. Ob istoricheskom edinstve russkikh i ukraintsev [On the historical unity of Russians and Ukrainians]. URL: https://russian.rt.com/world/article/88468-putin-statya-rossiya-urraina (date of access: 07.09.2021). (In Russ.)

Rossiia i postsovetskie strany: voprosy ekonomicheskikh otnoshenii [Russia and post-Soviet countries: issues of economic relations] / Ed. by A.G. Pylin: Moscow: Institute of Economics RAN, 2021. 232 p. (In Russ.)

Suspil'no-politichni orientatsii naselennia Ukraini: kviten' 2020 [Social and political organization of the population of Ukraine: April 2020] URL: https://www.kiis.com.ua/materials/pr/2020006_pressconf/Tables.pdf (date of access: 05.09.2021). (In Ukr.)

Tolochko P. Ukraina mezhdu Rossiei i Zapadom: istoriko-publitsisticheskie ocherki [Ukraine between Russia and the West: historical and journalistic essays. St. Petersburg: Izdatel'stvo SanktPeterburgskogo gumanit universiteta profsoiuzov, 2018. 592 p. (In Russ.)

Ukrainskii krizis: mezhdunarodnoe sopernichestvo i predely prochnosti gosudarstva [Ukrainian crisis: international rivalry and limits of strength of the state]. Ed. by N.Y. Silaev, A.A. Sushentsov. Moscow: Ves' mir, 2020. 280 p. (In Russ.)

Ukrainskii vopros $\mathrm{v}$ russkoi patrioticheskoi mysli [The Ukrainian question in Russian patriotic thought]: col. of doc. A.Yu. Minakov. Moscow: Book World, 2016. 800 p. (In Russ.)

Uyama T. Vliianie peremen perioda perestroiki na stanovlenie politicheskikh sistem stran Tsentral'noi Azii: chuvstvo ugrozy i avtoritarizm [The impact of the changes of the perestroika period on the formation of the political systems of the countries of Central Asia: a sense of threat and authoritarianism]. Mezhdunarodnaia analitika [International analytics]. 2021. Vol. 12. N 1. P. 55-70. (In Russ.)

Vseobshchaia Deklaratsiia prav cheloveka [The universal declaration of human rights]: Full version. URL: https://www.coe.int./ru/web/compass/the-universal-declaration-of-human-rights-fullversion- (date of access: 08.09.2021). (In Russ.) 